\title{
Author Correction: Repurposing type I-F CRISPR-Cas system as a transcriptional activation tool in human cells
}

Yuxi Chen, Jiaqi Liu, Shengyao Zhi, Qi Zheng, Wenbin Ma (D), Junjiu Huang, Yizhi Liu, Dan Liu, Puping Liang (iD) \& Zhou Songyang

Correction to: Nature Communications https://doi.org/10.1038/s41467-020-16880-8; published online 19 June 2020.

The original version of this Article contained an error in the author affiliations.

Affiliation 1 incorrectly read 'The Second Affiliated Hospital, Sun Yat-sen University; MOE Key Laboratory of Gene Function and Regulation and Guangzhou Key Laboratory of Healthy Aging Research, School of Life Sciences, Sun Yat-sen University, Guangzhou, 510275, China' instead of the correct 'Sun Yat-Sen Memorial Hospital, Sun Yat-sen University; MOE Key Laboratory of Gene Function and Regulation and Guangzhou Key Laboratory of Healthy Aging Research, School of Life Sciences, Sun Yat-sen University, Guangzhou, 510275, China'.

This has now been corrected in both the PDF and HTML versions of the Article.

Published online: 09 July 2020

(c) Open Access This article is licensed under a Creative Commons Attribution 4.0 International License, which permits use, sharing, adaptation, distribution and reproduction in any medium or format, as long as you give appropriate credit to the original author(s) and the source, provide a link to the Creative Commons license, and indicate if changes were made. The images or other third party material in this article are included in the article's Creative Commons license, unless indicated otherwise in a credit line to the material. If material is not included in the article's Creative Commons license and your intended use is not permitted by statutory regulation or exceeds the permitted use, you will need to obtain permission directly from the copyright holder. To view a copy of this license, visit http://creativecommons.org/licenses/by/4.0/.

(c) The Author(s) 2020 